Research article

\title{
Chloride or sulfate? Consequences for ozonation of textile wastewater
}

\author{
Yalcin Askin Oktem ${ }^{\mathrm{a}, *}$, Burak Yuzer ${ }^{\mathrm{a}}$, Muhammed Iberia Aydin ${ }^{\mathrm{a}}$, Hatice Eser Okten ${ }^{\mathrm{b}}$, \\ Sureyya Meric ${ }^{c}$, Huseyin Selcuk ${ }^{\mathrm{a}}$
}

${ }^{a}$ Istanbul University - Cerrahpasa, Engineering Faculty, Environmental Engineering Dept. Avcilar, Istanbul, Turkey

${ }^{\mathrm{b}}$ Izmir Institute of Technology, Engineering Faculty, Environmental Engineering Dept.,Gulbahce, Urla, Izmir, Turkey

${ }^{\mathrm{c}}$ Namik Kemal University, Engineering Faculty, Environmental Engineering Dept., Corlu 59860, Tekirdag, 59860, Turkey

\section{A R T I C L E I N F O}

\section{Keywords:}

Adsorbable organic halogens

Ozonation

Reactive dye

Treatment

Textile wastewater

Toxicity

\begin{abstract}
A B S T R A C T
Ozonation of chloride-rich textile wastewater is a common pretreatment practice in order to increase biodegradability and therefore meet the discharge limits. This study is the first to investigate ozone-chloride/bromide interactions and formation of hazardous adsorbable organic halogens (AOX) in real textile wastewater. Initially effect of ozonation on chloride-rich real textile wastewater samples were investigated for adsorbable organic halogens (AOX) formation, biodegradability and toxicity. After $15 \mathrm{~min}$ of ozonation, maximum levels of chlorine/bromine generation $(0.3 \mathrm{mg} / \mathrm{l})$ and AOX formation $(399 \mathrm{mg} / \mathrm{l})$ were reached. OUR and SOUR levels both increased by approximately $58 \%$. Daphnia magna toxicity peaked at $100 \%$ for $10 \mathrm{~min}$ ozonated sample. Considering adverse effects of ozonation on chloride-rich textile industry effluents, we proposed replacement of $\mathrm{NaCl}$ with $\mathrm{Na}_{2} \mathrm{SO}_{4}$. Comparative ozonation experiments were carried out for both chloride and sulfate containing synthetic dyeing wastewater samples. Results showed that use of sulfate in reactive dyeing increased biodegradability and decreased acute toxicity. Although sulfate is preferred over chloride for more effective dyeing performance, the switch has been hampered due to sodium sulfate's higher unit cost. However, consideration of indirect costs such as contributions to biodegradability, toxicity, water and salt recovery shall facilitate textile industry's switch from chloride to sulfate.
\end{abstract}

\section{Introduction}

Textile is one of the most water intensive industries that also uses large quantities of dyes, salts, surfactants, chemicals, and additives of hazardous nature in the process (Arslan-Alaton et al., 2005; Bisschops and Spanjers, 2003; Meriç et al., 2005a; Selçuk et al., 2006). Effluents from textile industry are highly colored due to frequently used alkaline dyes and are characterized by high salinity and ecotoxicity. Aside from dyes, effluents may contain biocides, chlorophenols, carcinogenic amines, free formaldehyde, surfactants, disinfectants, solvents, softeners, heavy metals, and salts (Jadhav et al., 2015). Therefore, textile industry wastewater streams may be resistant to biodegradation and photodegradation (Arslan-Alaton et al., 2004; Asghar et al., 2015), passing through conventional treatment plants almost unaltered in form. Nevertheless, some dyes (disperse, vat, direct and basic) are adsorbed onto activated sludge (Frijters et al., 2006) and therefore can be removed successfully. However, due to high solubility and non-biodegradability, reactive dyes are very difficult to remove using biodegradation as the sole treatment method (Khatri et al., 2015). Advanced oxidation processes (AOPs) are emerging technologies for treatment and detoxification of hazardous chemical compounds. Ozonation is a commercially available AOP which destructs toxic and/or nonbiodegradable compounds, provides oxygenation in wastewater and does not generate sludge (Asghar et al., 2015). Therefore, ozonation not only facilitates decolorization, but also enhances biodegradability (Sarayu et al., 2007; Somensi et al., 2010) and detoxification (Asghar et al., 2015; Selcuk, 2005; Somensi et al., 2010) depending on pH. On the other hand, ozonation and electrochemical advanced oxidation systems are known to oxidize chloride to chlorine/bromine and to form chlorinated by-products (Garcia Segura et al., 2018; Ramjaun et al., 2011; Santhanam et al., 2017; Lan et al., 2017; Jalife-Jacobo et al., 2016). Yuan et al. (2012) investigated dye degradation efficiency in $\mathrm{UV} / \mathrm{TiO}_{2}$ process for a wide range of salinity and $\mathrm{pH}$ values. Higher $\mathrm{Cl}^{-}$ concentration not only inhibited dye degradation, but also increased concentration of halogenated compounds. Moreover, several toxic chlorinated by-products were identified during dye degradation. It is evident that integration of different treatment processes is necessary if we wish to reuse the textile wastewater (Tong and Elimelech, 2016). Recently, a hybrid approach of advanced oxidation prior to biodegradation is found to be the most environmentally friendly and

\footnotetext{
* Corresponding author.

E-mail address: oktemy@istanbul.edu.tr (Y.A. Oktem).
} 
economically feasible one, among available treatment techniques (Asghar et al., 2015; Imran et al., 2015). Although a multitude of studies on $\mathrm{O}_{3}$-integrated biological treatment of dyes was reported (Bonakdarpour et al., 2011; Chougule et al., 2014; Eremektar et al., 2007; Liang et al., 2018; S. Meriç et al., 2005b; Popli and Patel, 2015), most of them did not investigate the chloride factor. Chloride cannot be overlooked while studying $\mathrm{OH}$ radical-based AOPs, since it is a major ion in textile wastewaters. Especially ozonation and electrochemical oxidation processes are affected due to oxidation of chloride to chlorine/bromine and subsequent formation of halogenated organic/ inorganic by-products (Selcuk et al., 2004; Zanoni et al., 2004). Halogenated organic compounds that are adsorbable on activated carbon Adsorbable Organic Halides (AOX) may form by chlorine reacting with many compounds that are present in real textile wastewater (Baycan et al., 2007). Discharge of AOX compounds into environment is a concern due to their carcinogenic, mutagenic, acute, chronic and cytotoxic effects (Turcanu and Bechtold, 2017; Xie et al., 2017, 2018). During ozonation, one of many AOX generation routes is via hydroxyl and chloride radical reactions. Chloride ions may act as $\mathrm{OH}$ radical traps (Reactions 1 and 2), forming chloride radicals, which can act upon double bonds of organic compounds (Reactions 3 and 4). Thus chlorinated hydrocarbons are formed and an increase in AOX concentration is observed (Wang et al., 2017).

$\cdot \mathrm{OH}+\mathrm{Cl}^{-} \rightarrow{ }^{\cdot} \mathrm{ClOH}^{-}$

${ }^{\circ} \mathrm{ClOH}^{-}+\mathrm{H}^{+} \rightarrow \mathrm{Cl}^{-}+\mathrm{H}_{2} \mathrm{O}$

$\mathrm{Cl}^{\cdot}+\mathrm{R}_{2} \mathrm{C} \mathrm{CR}_{2} \rightarrow \mathrm{R}_{2} \mathrm{ClC}^{*}-\mathrm{CR}_{2}$

$\mathrm{Cl}^{*}+\mathrm{R}_{2} \mathrm{C} \mathrm{CR}_{2} \rightarrow \mathrm{R}_{2} \mathrm{ClC}^{*}-\mathrm{CR}_{2} \rightarrow$ chlorohydrocarbons (formation of AOX)

Thus, chloride ion interferes with decomposition of organic pollutants in oxidation processes. Also, since chlorinated aromatic compounds may be more ecotoxic than the parent dye (Vacchi et al., 2013; Pinheiro et al., 2004), chloride ion may hamper degradation efficiency at the following biological treatment stage (Farooqi and Basheer, 2017; Tomei et al., 2016). In contrast to chloride ions, use of sulfate in dyeing process is expected to produce less AOX due to absence of reactivity with ozone. Also use of sulfate as electrolyte may produce wastewaters that have a potential to increase the overall treatment capacity of anaerobic biological treatment and bioenergy production in microbial fuel cells via sulfur reducing bacteria (Lee et al., 2012; Miran et al., 2018; Zeng et al., 2017).

In this study, our principal aim was to investigate ozone-halogen interaction and to elucidate the formation of AOX in real and synthetic textile wastewater. Since chloride was directly related with a number of issues regarding ozonation of textile wastewater, its replacement with sulfate was proposed. To the best of our knowledge, this is the first study on formation of AOX during ozonation of a real textile wastewater and its effect on biodegradability of real synthetic-cotton textile wastewater. As the pioneering part of this study, use of sulfate instead of chloride was investigated in terms of oxygen uptake rate (OUR) and ecotoxicity to Vibrio fischeri and Daphnia magna.

\section{Material and methods}

\subsection{Sampling and preparation of synthetic textile sample}

Textile wastewater samples were taken from three cotton-synthetic textile factories located in Torbali (Izmir), Gumusler (Denizli) and Esenyurt (Istanbul) industrial zones in Turkey. In those factories, production line included baths of reactive dyeing, rinsing, washing, scoring, and peroxide bleaching. Composite samples ( $24 \mathrm{~h}$ ) were collected in spring and winter of 2016 from equalization tanks, which were located at the end of the production line, prior to wastewater treatment plant. Samples were stored at $4{ }^{\circ} \mathrm{C}$ to keep chemical composition intact.
Two different synthetic dyeing solutions were prepared using Reactive Black 5 by simulating dyeing procedure of the factories. Also, while one of the solutions contained chloride as the salt ion, the other one had sulfate.

\subsection{Ozonation}

Ozone $\left(\mathrm{O}_{3}\right)$ was generated with a Sander Model 300.5 generator. Pure oxygen with a flow rate of $500 \mathrm{NL} / \mathrm{h}$ was fed to the generator which operated at $250 \mathrm{~mA}$ current. Generated ozone had a flow rate and concentration of $4.5 \mathrm{~g} \mathrm{O}_{3} / \mathrm{h}$ and $14 \mathrm{~g} \mathrm{O}_{3} / \mathrm{m}^{3}$, respectively. Generated $\mathrm{O}_{3}$ was fed to a cylindrical glass contact reactor $(100 \mathrm{~cm}$ length, $10 \mathrm{~cm}$ diameter). Ozonation performance was monitored for operation times up to $20 \mathrm{~min}$. Ozone trap with $20 \mathrm{~g} / \mathrm{l} \mathrm{KI}$ was setup at the end of the contact reactor in order to analyze production rate and reacted concentration. At first $\mathrm{O}_{3}$ gas was directly supplied to $\mathrm{O}_{3}$ trap filled with KI solution for different time periods and then $\mathrm{O}_{3}$ analyses were performed according to procedure in method 2350 D (APHA, AWWA, 2012).

\subsection{Biodegradability}

Oxygen uptake rate analysis is a common technique used in measuring metabolic activities of organisms in aerobic biological wastewater treatment systems. Microorganisms use oxygen as the electron acceptor to oxidize organic matter. High OUR indicates high biological activity. We determined OUR rate through a series of dissolved oxygen (DO) measurements over time. Expression of OUR on the basis of volatile suspended solids data yielded specific oxygen uptake rate (SOUR) as given in Equations (1) and (2). VSS concentrations were obtained from routine daily solids analysis $(\mathrm{mg} / \mathrm{l})$.

OUR $=m g \mathrm{O}_{2} / L / h$

SOUR $=\frac{\text { Uptake rate } * 1000}{V S S}$

\subsection{Acute toxicity}

In order to estimate the potential toxicity that might arise from ozonation of real textile wastewater, ecotoxicity of effluents prior to and following ozone treatment was assessed by Daphnia magna standard acute test (ISO 6341:2012, 2012). Effluents from biological treatment were also tested. Daphnids were grown at $16 \mathrm{~h}$ day light $-8 \mathrm{~h}$ dark cycles supplying 3000 lux illumination at $20^{\circ} \mathrm{C}$ room temperature and were fed Selenastrum capricornutum $(300,000 \mathrm{cell} / \mathrm{ml})$ and baker's yeast (Schizosaccharomyces cerevisiae, 200,000 cell/ml). A minimum $6 \mathrm{mg} / 1$ of dissolved oxygen was supplied in vivarium reactors by air pumps and $\mathrm{pH}$ of the medium was adjusted to 8.0. Newborn daphnids ( $>24 \mathrm{~h}$ ) were exposed to $50 \%$ diluted samples for $24 \mathrm{~h}$. Four replicates were tested in dark at $20^{\circ} \mathrm{C}$, using five daphnids in each vessel with $50 \mathrm{~mL}$ sample volume. Toxicity of each sample was assessed by means of immobilization percentage that was determined by dividing total number of immobilized organisms to total number of tested organisms. Bacterial (Vibrio fischeri) luminescence inhibition test (Lumistox, Dr. Bruno Lange, Düsseldorf, Germany) was conducted according to ISO guidelines (Iso $6341: 2012,2012$ ) at $15 \pm 1{ }^{\circ} \mathrm{C}$ and $\mathrm{pH} 7$, with salinity adjustment to $35 \%$. Exposure time was $30 \mathrm{~min}$. Lyophilized bacterial reagent was obtained from Deutsche Sammlung von Mikroorganismen und Zellkulturen (DSM-7151, Braunschweig, Germany). Each sample dilution (or control) was performed in triplicate. $\mathrm{EC}_{50}$ values for the Lumistox test were calculated by graphical interpolation, in accordance with ISO guidelines (ISO 6341:2012, 2012). 


\subsection{Analytical methods}

Chemical Oxygen Demand (COD), Total Organic Carbon (TOC), 5day Biological Oxygen Demand $\left(\mathrm{BOD}_{5}\right)$, alkalinity, Total Suspended Solids (TSS) and Volatile Suspended Solids (VSS) were analyzed according to Standard Methods (APHA, AWWA, 2012). Hach DR5000 UVVis spectrophotometer was used for color and absorbance measurements. Conductivity and $\mathrm{pH}$ measurements were done using a $\mathrm{HACH}$ HQ40D portable multimeter. TOC measurements were carried out with Shimadzu TOC-CPN TOC analyzer. Chloride and bromide concentrations were measured using ion chromatography. Chlorine generation during ozonation was monitored by standard DPD method. Due to possible bromine interference with chlorine measurement method, from now on we will refer to chlorine measurements as chlorine/bromine measurements. Activated carbon adsorption was used to determine AOX concentration (International code: TS EN ISO 9562:2004).

\section{Results and discussion}

\subsection{Generation of chlorine/bromine during ozone treatment in real wastewater (RW)}

Chemical and physical characterization of real and synthetic wastewater samples were given in Table 1 . In cotton textile industry salt is used as electrolyte in dyeing process, yielding to chloride concentrations up to $70 \mathrm{~g} / \mathrm{l}$. Due to mixing of dyeing effluents with effluents from domestic sources and other processes, average chloride concentration was measured approximately as $1860 \mathrm{mg} / \mathrm{l}$. Chloride concentrations from three factories were observed to be in a wide range (Table 1).

Although there was no direct bromide use in textile processes, it was detected and measured in effluents (Table 1). We believe that domestic wastewater and impurities in bulk $\mathrm{NaCl}$ solution that was used in dyeing baths were the major bromide sources in effluents. Furthermore, bulk $\mathrm{Cl} / \mathrm{Br}$ mass ratios in the range of $1900-8700$ have been reported previously (Alcalá and Custodio, 2008; Davis et al., 1998). Although chloride mechanism has been studied extensively, bromide in textile wastewater has not been investigated before. During ozonation, chloride and bromide may react with ozone to produce chlorine and bromine with reaction rate constants of $0.003 \mathrm{M}^{-1} \mathrm{~s}^{-1}$ and $160 \mathrm{M}^{-1} \mathrm{~s}^{-1}$, respectively (Table 2). Although concentration of chloride in effluent was significantly higher than bromide concentration (Table 1), $\mathrm{O}_{3}-\mathrm{Br}^{-}$reaction rate was 50,000 times faster than that of $\mathrm{O}_{3}-\mathrm{Cl}^{-}$(Table 2). Thus bromide level was one of the important factors to control in production of hazardous halogenated by-products in salt rich industrial wastewaters. In textile wastewater, even if chlorine was produced due to high chloride concentration, it rapidly converted to bromine (Table 2).

Hypochlorous/hypobromous acids are dominant reactive species with which majority of organic compounds yield to halogenated products. Real textile wastewater contains many different organic groups

Table 1

Characterization of real (RW) and synthetic textile wastewaters (SW).

\begin{tabular}{lllll}
\hline & & RW & SW & \\
\hline Parameter & & & Chloride & Sulfate \\
BOD $_{5}$ & $\mathrm{mg} / 1$ & $128 \pm 12$ & 102 & 95 \\
$\mathrm{COD}$ & $\mathrm{mg} / 1$ & $505 \pm 67$ & 185 & 180 \\
$\mathrm{TOC}$ & $\mathrm{mg} / 1$ & $527 \pm 112$ & 39 & 41 \\
$\mathrm{pH}$ & - & $8.1 \pm 1$ & 8.0 & 8.0 \\
Bromide & $\mathrm{mg} / 1$ & $0.68-1.20$ & - & - \\
Chloride & $\mathrm{mg} / 1$ & $800-5500$ & 5800 & - \\
Sulfate & $\mathrm{mg} / 1$ & - & - & 6435 \\
Color & $\mathrm{Pt}-\mathrm{Co}$ & $387 \pm 204$ & 1352 & 1413 \\
\hline
\end{tabular}

${ }^{\text {a }}$ Average values for composite samples taken from three factories except for chloride and bromide concentration values. Those were reported as range of values.
Table 2

Ozone-chloride, ozone-bromide and chlorine-bromide reactions with corresponding rate constants (Yang and Pignatello, 2017).

\begin{tabular}{ll}
\hline Ozone-chloride reactions & Rate constants $\left(\mathrm{M}^{-1} \mathrm{~s}^{-1}\right)$ \\
\hline $\mathrm{O}_{3}+\mathrm{Cl}^{-} \rightarrow \mathrm{OCl}_{-}+\mathrm{O}_{2}$ & 0.003 \\
$\mathrm{O}_{3}+\mathrm{OCl}^{-} \rightarrow 2 \mathrm{O}_{2}+\mathrm{Cl}^{-}$ & 110 \\
$\mathrm{O}_{3}+\mathrm{OCl}^{-} \rightarrow \mathrm{O}_{2}+\mathrm{ClO}_{2}^{-}$ & 30 \\
$\mathrm{O}_{3}+\mathrm{ClO}_{2}^{-} \rightarrow \mathrm{ClO}_{3}^{-}+\mathrm{O}_{2}$ & $4.10^{6}$ \\
$\mathrm{HOCl} \rightarrow \mathrm{OCl}^{-}+\mathrm{H}^{+}$ & 7.54 \\
$\mathrm{Ozone}_{-} \mathrm{bromide}^{-}$reactions & Rate constants $\left(\mathrm{M}^{-1} \mathrm{~s}^{-1}\right)$ \\
$\mathrm{O}_{3}+\mathrm{Br}^{-} \rightarrow \mathrm{OBr}_{-}+\mathrm{O}_{2}$ & 160 \\
$\mathrm{O}_{3}+\mathrm{OBr}^{-} \rightarrow 2 \mathrm{O}_{2}+\mathrm{Br}^{-}$ & 330 \\
$\mathrm{O}_{3}+\mathrm{OBr}^{-} \rightarrow \mathrm{O}_{2}+\mathrm{BrO}_{2}^{-}$ & 100 \\
$\mathrm{O}_{3}+\mathrm{HOBr}^{-} \mathrm{O}_{2}+\mathrm{BrO}_{2}{ }^{-}+\mathrm{H}^{+}$ & $<0.013$ \\
$\mathrm{HOBr} \rightarrow \mathrm{OBr}^{-}+\mathrm{H}^{+}$ & 8.8 \\
$\mathrm{Chlorine}-\mathrm{bromide}$ reaction & Rate constant $\left(\mathrm{M}^{-1} \mathrm{~s}^{-1}\right)$ \\
$\mathrm{HOCl}+\mathrm{Br}^{-} \rightarrow \mathrm{HOBr}+\mathrm{Cl}^{-}$ & $2.95 \times 10^{3}$ \\
\hline
\end{tabular}

such as saturated and unsaturated chromophores (Morali et al., 2016; Waring et al., 1990). Azo and anthraquinone are the most important chromophore groups since they are widely used (Farooqi and Basheer, 2017). Although hypochlorous acid reactions with unsaturated bonds are generally slow or negligible, in some cases, chromophore groups in dye molecules may have high chlorine reactivity (Zhang et al., 2009). Real textile wastewater ozonation experiments revealed that with a linear ozone consumption, approximately $1180 \mathrm{mg} / 1 \mathrm{O}_{3}$ reacted for the duration of experiment. Chlorine/bromine generation of $0.1 \mathrm{mg} / \mathrm{l}$ was observed in $10 \mathrm{~min}$, increasing up to $0.3 \mathrm{mg} / 1(15 \mathrm{~min})$ and then it started to decrease, reaching a plateau at $30 \mathrm{~min}$ (Fig. 1). Results showed that formation and quenching/destruction of chlorine/bromine species occurred simultaneously.

\subsection{Formation of AOX during ozonation of real textile wastewater(RW)}

In textile industry, although chlorine was replaced by hydrogen peroxide for bleaching, it was still used in scouring solution for dyeing machines. Thus AOX concentration in effluent was mostly attributed to the final cleaning step of dyeing process. AOX concentration was found to be $3.4 \mathrm{mg} / 1$ in raw textile wastewater (Fig. 1). During ozonation, AOX concentration reached a maximum of $399 \mathrm{mg} / \mathrm{l}$ in $15 \mathrm{~min}$. Following a similar trend as free chlorine/bromine concentration did, AOX concentration decreased sharply after $15 \mathrm{~min}$, becoming almost nondetectable at $45 \mathrm{~min}$. UV-Vis spectra of raw textile wastewater and its ozonated samples were given in Fig. 2. Results for $15 \mathrm{~min}, 20 \mathrm{~min}$ and 25 min ozonated samples converged throughout the spectrum. Thus we concluded that maximum AOX formation and efficient color

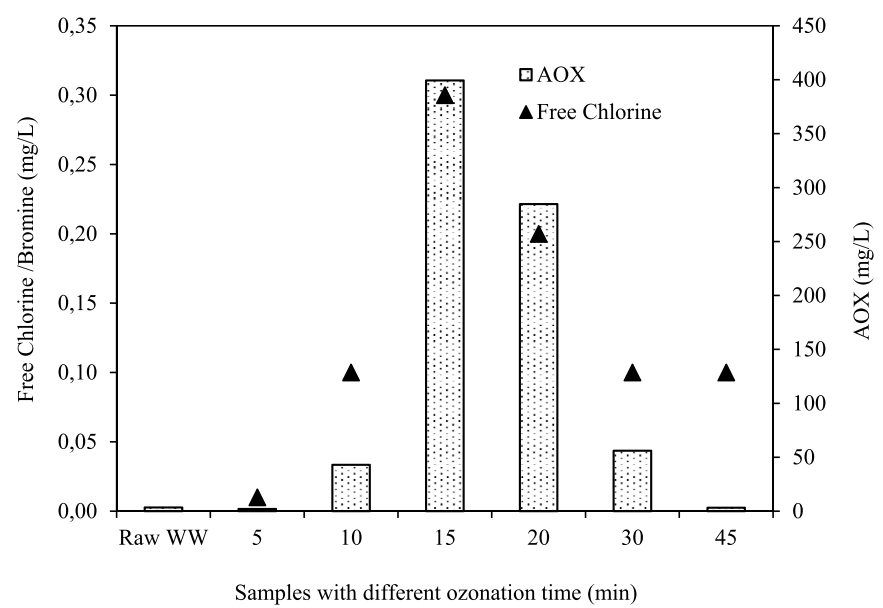

Fig. 1. Formation of AOX and free chlorine/bromine during ozonation of real wastewater. 


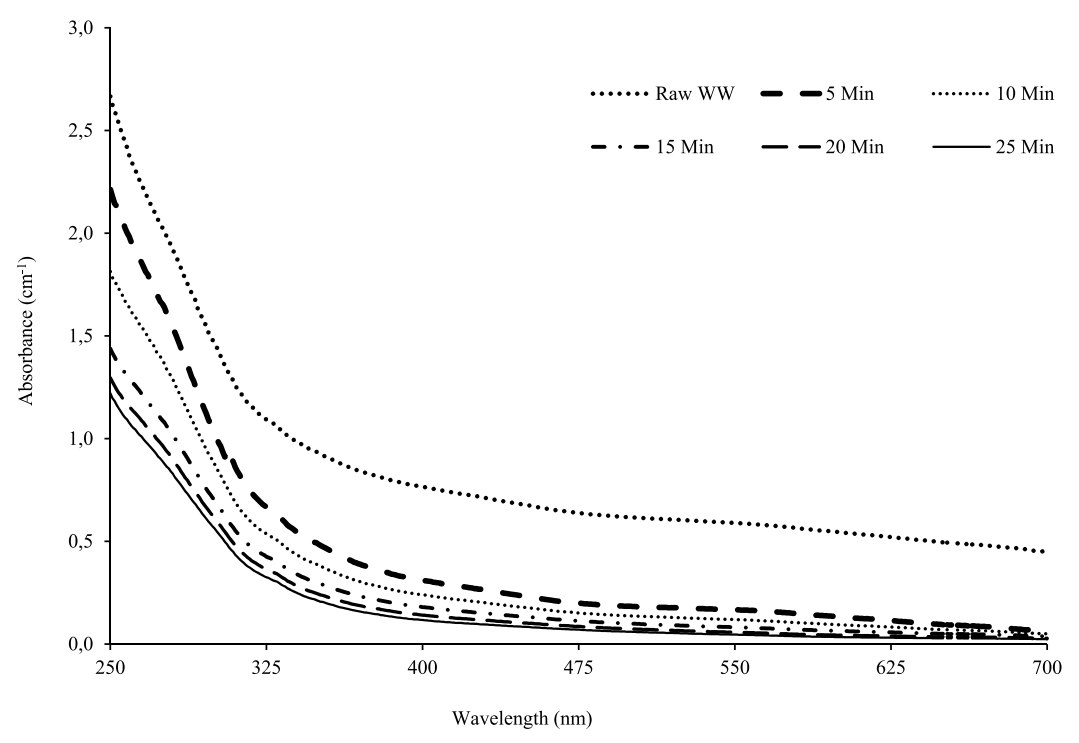

Fig. 2. Color degradation in real textile wastewater due to varying ozonation periods.

degradation occurred in the same ozonation time period. Results also reflected the fact that ozonation of $\mathrm{Cl}^{-}$-rich wastewater matrices might not be preferable due to formation of toxic by-products. Furthermore, Grguric et al. (1994) investigated the effect of bromide impurity on formation of brominated by-products in ozonation process. They found that even in an artificial seawater system, where bromide ion was not present, trace bromide impurity was the dominant oxidized species during ozonation. Furthermore, Deeudomwongsa et al. (2017) investigated the effect of chloride ions on halogenated by-products and concluded that chloride addition not only induced changes in speciation of halogenated by-products, but also increased halogenated byproduct formation potentials by 2 -fold. Thus, formation of high concentrations of AOX in ozonated textile wastewater may be also attributable to bromide impurity in used salt.

\subsection{Effect of ozonation on the biodegradability and toxicity of real textile wastewater (RW)}

As measures of biodegradability we used OUR, SOUR and $\mathrm{BOD}_{5} /$ COD ratio parameters. In microbial processes, stoichiometry and environmental conditions lead the consumption of electron donor and electron acceptor molecules. OUR is the amount of oxygen required to decompose a given electron donor, namely organic matter, at steady state in a given period of time. The change of TOC which required for biological systems, according to $\mathrm{pH}$ and temperature during ozonation can be seen Fig. 3.

Specific oxygen uptake rate is obtained by dividing OUR by sludge concentration, establishing the microbial activity connection (Yoon, 2015). If there were any toxic compounds present to deteriorate microbial activity, OUR and SOUR results would decrease. OUR was calculated from dissolved oxygen mass balance in the reactor.

OUR $=K_{L} a\left(C_{s}-C_{\text {end }}\right)-\frac{d C}{d t}$

where $\mathrm{C}$, Cs, and $\mathrm{C}_{\mathrm{end}}$ are dissolved oxygen concentrations (mg/l) of the sample at saturation and during endogenous respiration respectively (Contreras et al., 2008). $\mathrm{K}_{\mathrm{L}}$ a is Oxygen transfer coefficient. Oxygen used by suspended microorganisms in wastewater depends on gas/bulk liquid/cell membrane transfer rates and microbial growth rates (GarciaOchoa and Gomez, 2009). In this study, we investigated substrate utilization rate of aerobic microbial community that was exposed to ozonated real wastewater samples by measuring oxygen uptake. OUR and SOUR results were in agreement to point out that the maximum

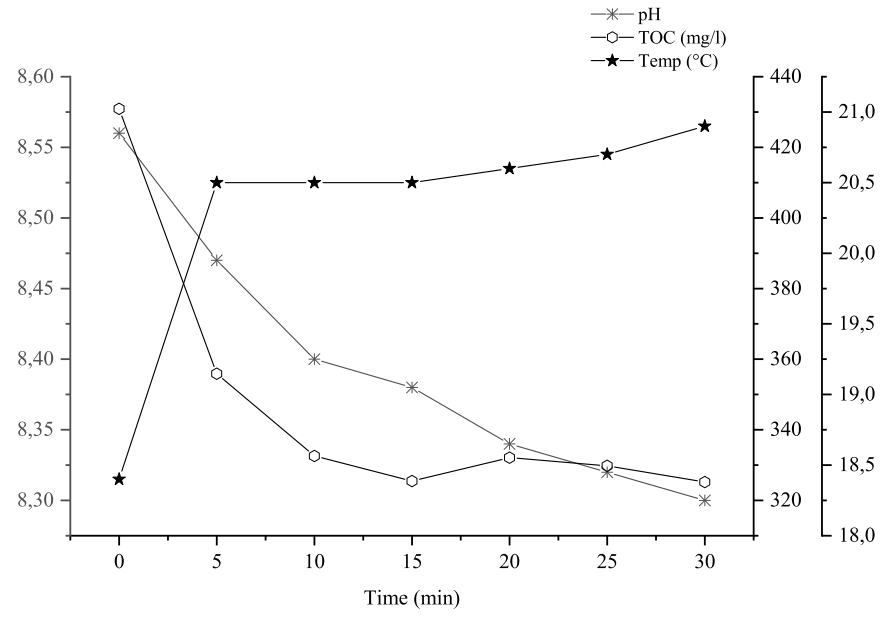

Fig. 3. Change of TOC during ozonation according to $\mathrm{pH}$ and temperature.

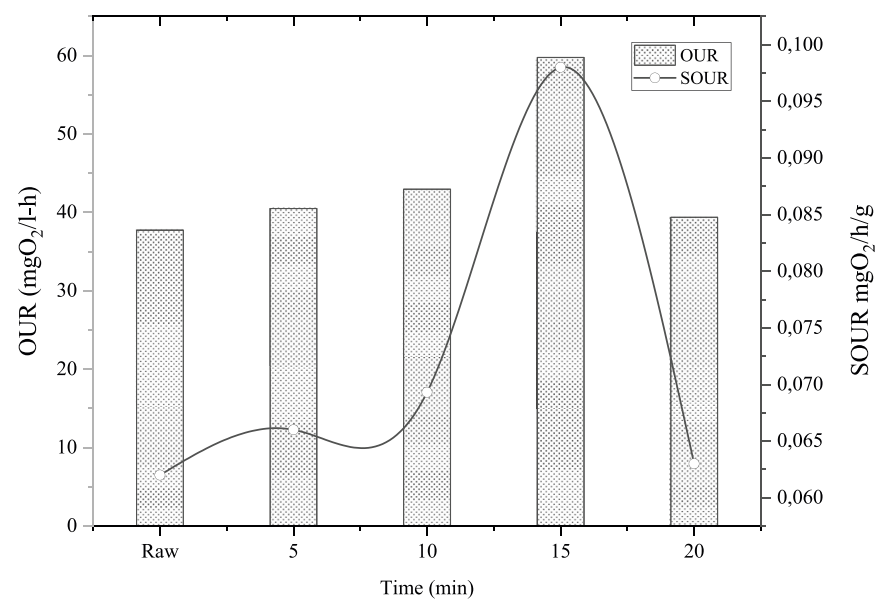

Fig. 4. OUR and SOUR levels at textile wastewater depending on time.

biodegradability was achieved at 15 min ozonation (Fig. 4). While OUR and SOUR results for $5 \mathrm{~min}$ and $10 \mathrm{~min}$ ozonated samples were following an increasing trend when compared to raw wastewater, $20 \mathrm{~min}$ measurement gave a similar result. When maximum AOX formation 


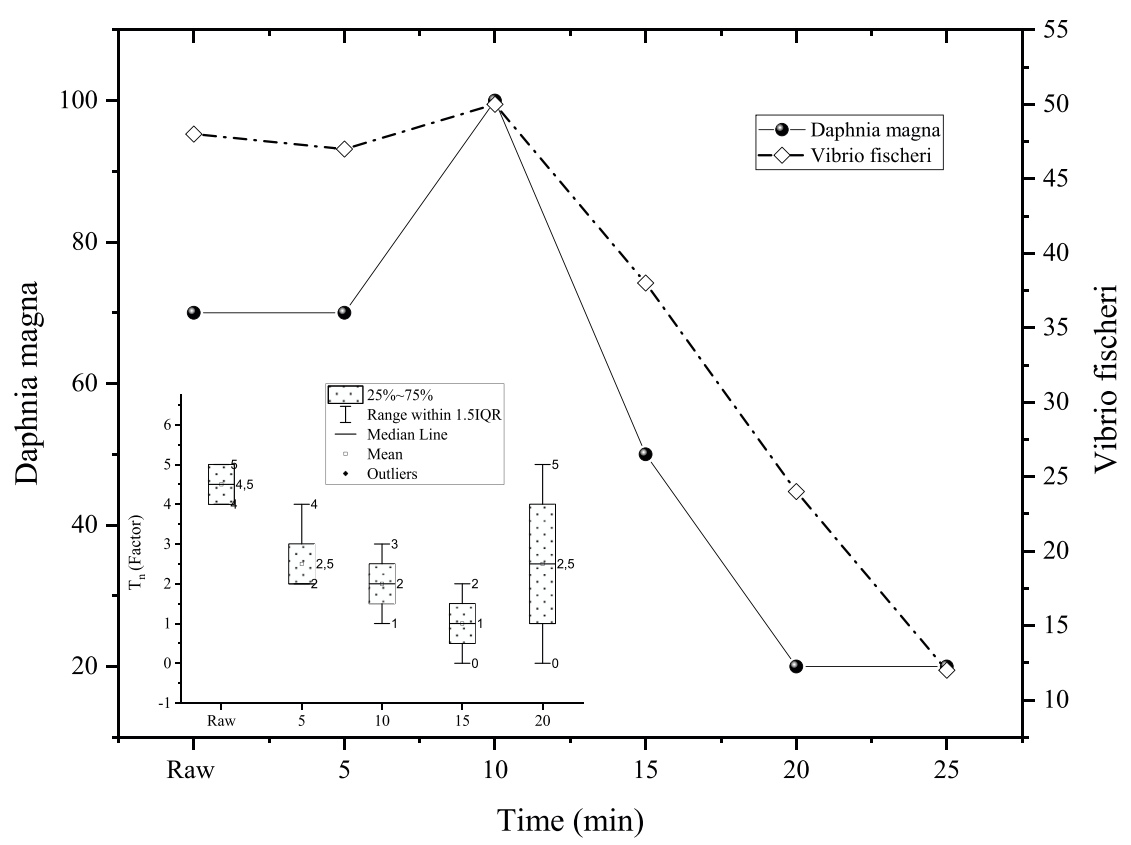

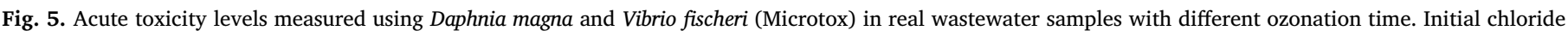
concentration was $5500 \mathrm{mg} / \mathrm{l}$ for Daphnia magna experiments.

was observed (Fig. 1), biodegradability of ozonated wastewater was also at its highest (at 15th min) (Fig. 4).

Ozonation creates a very dynamic environment, where radicals and AOX species were formed and consumed simultaneously. In a mixed microbial consortium, like the one that was used for OUR and SOUR experiments, microorganisms were able to harvest the maximum energy from $15 \mathrm{~min}$ ozonated wastewater sample. The decrease in biodegradability for $20 \mathrm{~min}$ ozonated sample might be due to formation of less biodegradable by-products. Acute toxicity of raw wastewater to Daphnia magna was observed as $70 \%$ immobilization (Fig. 5). Five minutes of ozonation did not make a difference in the toxicity level of real textile effluent. However, prolonging ozonation time to $10 \mathrm{~min}$ resulted in $100 \%$ immobilization. This could be explained by increasing concentration of by-products with ozonation time (Imran et al., 2015; Meriç et al., 2005a). Our findings were in accordance with the study by Fang et al. (2016), where researchers reported a relation between AOX formation and aquatic toxicity during 2,4,6-trichlorophenol degradation in a $\mathrm{Co}(\mathrm{II}) /$ peroxymonosulfate $/ \mathrm{Cl}^{-}$system. Xie et al. (2017) also reported a relation between AOX levels and genotoxicity of AOX-containing pharmaceutical wastewater. By increasing ozonation time to 15 min, toxicity to $D$. magna decreased to $50 \%$, and continued to decrease till $20 \%$ by $20 \mathrm{~min}$ of ozonation. These results were consistent with AOX profile shown in Fig. 1. Toxicity increased in parallel to chlorine/bromine measurements, however maximum toxicity was observed for 10 min ozonation sample which was caused by dual effect of chloride and AOX on microorganisms. In Microtox experiments (Fig. 5, Vibrio fischeri), toxicity results for raw effluent, 5 min ozonated sample and $10 \mathrm{~min}$ ozonated sample were similar. Toxicity level increased for prolonged ozonation times in real textile wastewater samples, indicating a similarity with Daphnia magna results and with the formation of AOX (Fig. 1).

The difference in toxicity response of two organisms could be explained by their natural habitat. Daphnia magna is known to live in freshwater ecosystems, whereas Vibrio fischeri is used to salty media as it is a natural inhabitant of seawater. Dual effect of AOX concentration generated in $10 \mathrm{~min}$ of ozonation and remaining salt concentration was enough to immobilize whole Daphnia magna community, but it affected only half of Vibrio fischeri community. Once salt concentration in effluent was spent in formation of AOX, we observed a decrease in toxicity response of $D$. magna. Our results supported previous findings reported by Somensi et al. (2010), who observed formation of various organic by-products during ozonation of real textile wastewater. Ozonation was reported to be a very efficient oxidation method in improving the biodegradability of textile wastewater, which can thereafter be treated by biological processes (Chougule et al., 2014; UlucanAltuntas and Ilhan, 2018). However, in agreement with previous works (Magdeburg et al., 2014; Sarayu et al., 2007; Somensi et al., 2010), our results indicated that there was a risk of toxicity increase depending on ozonation period.

\subsection{Comparison studies with synthetic wastewater (SW) containing sulfate salt}

During dyeing process, negatively charged ions of dye and cellulose repel each other in the absence of salt, yielding to poor exhaustion. Salt neutralizes the negative charge of cellulose, increases affinity of dye towards cellulosic substrate, and thus facilitates exhaustion. Since reactive dyestuffs have lower affinity, more inorganic salt is required in order to accelerate absorption. Considering effectiveness and cost, both Glauber's salt $\left(\mathrm{Na}_{2} \mathrm{SO}_{4}\right)$ and common salt $(\mathrm{NaCl})$ are used in dyeing. While they are basically the same -sodium is the active cation in bothtype of anion is important in terms of subsequent reuse of wastewater. Use of sulfate instead of chloride may decrease formation of halogenated by-products and thus decrease toxicity levels in textile effluents. Chloride and its bromide impurity may affect formation and nature of ozonated organic by-products and thus decrease the detoxification efficiency of ozonation process (Yuan et al., 2012). Additionally, presence of sulfate in textile wastewater may form peroxodisulfate $\left(\mathrm{S}_{2} \mathrm{O}_{8}{ }^{2-}\right)$ ion in (photo)electrochemical advanced oxidation processes. Peroxodisulfate may further oxidize hazardous dyes to either complete mineralization $\left(\mathrm{CO}_{2}\right)$ or nonhazardous inorganic ions (Espinoza et al., 2016). Furthermore, communication with textile industry representatives revealed that use of $\mathrm{Na}_{2} \mathrm{SO}_{4}$ enables a much more efficient dyeing process. However, its use is hampered by its cost, which is higher than cost of $\mathrm{NaCl}$. In order to investigate the effect of salt type on by-product formation and toxicity, two reactive dye solutions were prepared with $\mathrm{NaCl}$ and $\mathrm{Na}_{2} \mathrm{SO}_{4}$, separately. Concentrations of chloride $(5800 \mathrm{mg} / \mathrm{l})$ and sulfate $(6435 \mathrm{mg} / \mathrm{l})$ were adjusted to simulate 
Table 3

Effect of ozonation on biodegradability, oxygen consumption rate and toxicity of chloride and sulfate containing synthetic wastewater.

\begin{tabular}{|c|c|c|c|c|c|c|c|c|}
\hline \multirow[b]{2}{*}{ Sample } & \multicolumn{4}{|c|}{$\mathrm{Cl}^{-}$containing } & \multicolumn{4}{|c|}{$\mathrm{SO}_{4}{ }^{2-}$ containing } \\
\hline & OUR (mg/l) & SOUR (mg/g) & BOD5/COD & Toxicity (\%) & OUR (mg/l) & SOUR (mg/g) & BOD5/COD & Toxicity (\%) \\
\hline SW & 2,79 & 0,0035 & 0,15 & 56 & 4,4 & 0,0053 & 0,25 & 43 \\
\hline $\mathrm{O}_{3} 15$ (min) & 2,74 & 0,0033 & 0,12 & 36 & 6,78 & 0,0086 & 0,44 & 18 \\
\hline
\end{tabular}

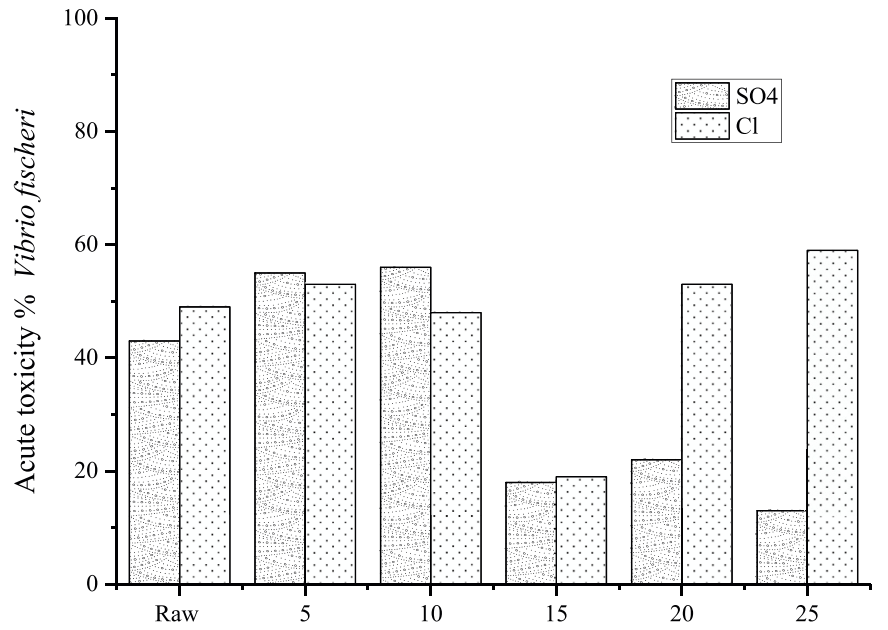

Fig. 6. Acute toxicity on Vibrio fischeri in synthetic samples on the presence of chloride and sulfate salts.

electrical conductivity levels required for efficient dyeing. Chloride and sulfate containing solutions were ozonated until color degradation reached a steady state level. Chlorinated compounds might absorb light at UV range of 250-350 nm (Kovács et al., 2016), thus color degradation was followed in both experiments. While biodegradability of $\mathrm{SO}_{4}{ }^{2-}$ $\mathrm{SW}$ was higher than that of $\mathrm{Cl}^{-}-\mathrm{SW}, 15 \mathrm{~min}$ ozonation has increased

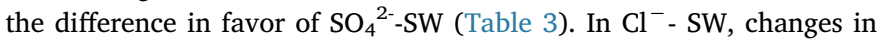
OUR and SOUR levels of pre- and post-ozonation samples were found to be insignificant $\left(<5 \%\right.$ ) while $\mathrm{BOD}_{5} / \mathrm{COD}$ ratio decreased around $20 \%$. In contrast, after ozonation, $\mathrm{BOD}_{5} / \mathrm{COD}$ ratio, OUR and SOUR levels in $\mathrm{SO}_{4}{ }^{2-}-\mathrm{SW}$ increased from $0.25 \mathrm{mg} / \mathrm{mg}, 0.44 \mathrm{mg} / \mathrm{l}$ and $0.053 \mathrm{mg} / \mathrm{l}$ to $0.44 \mathrm{mg} / \mathrm{mg}, 6.78 \mathrm{mg} / \mathrm{l}$ and $0.086 \mathrm{mg} / \mathrm{l}$, respectively (Table 3). Toxicity levels decreased with ozonation for both samples, $25 \%$ for $\mathrm{SO}_{4}{ }^{2-}$ - SW and $20 \%$ for $\mathrm{Cl}^{-}$- SW.

Acute toxicity results for sulfate and chloride containing synthetic samples were given in Fig. 6. Comparison of samples revealed that $5 \mathrm{~min}$ and $10 \mathrm{~min}$ ozonated $\mathrm{SO}_{4}{ }^{2-} \mathrm{SW}$ samples were more toxic than their chloride containing counterparts. After $10 \mathrm{~min}$ the trend was reversed and sulfate containing samples became less toxic. Especially at 15 min ozonation, which improved biodegradation significantly, toxicity of $\mathrm{SO}_{4}{ }^{2-}-\mathrm{SW}$ was only $18 \%$. In order to compare ozonation and chlorination, another synthetic dye solution was prepared without adding any salt and it was chlorinated until chlorine residual in solution was $0.3 \mathrm{mg} / \mathrm{l}$. Chlorination of dye solution inhibited biodegradability. Initial $0.25 \mathrm{BOD}_{5} / \mathrm{COD}$ ratio, $4.4 \mathrm{mg} / 1$ OUR and $0.053 \mathrm{mg} / 1$ SOUR decreased to $0.055 \mathrm{BOD}_{5} / \mathrm{COD}$ ratio, $0.97 \mathrm{mg} / 1$ OUR and $0.013 \mathrm{mg} / \mathrm{l}$ SOUR, respectively.

\section{Conclusions}

Textile industry generally uses an advanced oxidation process to pretreat its effluents prior to biological treatment in order to increase biodegradability and subsequently meet the discharge limits. Therefore, ozonation of chloride-rich textile wastewater is a common practice. In this study, we showed that ozonation increased toxicity due to AOX formation and chlorine/bromine generation. Consequently, the biological treatment process that followed ozonation would be expected to perform poorly and there would be refractory organic compounds remaining in the treated effluent. Since recovery and recycling of water was a requirement for textile industry, we proposed replacing chloride with sulfate. In this study, we showed that switching from chloride to sulfate decreased acute toxicity and improved biodegradability. Although sodium sulfate has a higher unit cost than sodium chloride, indirect contributions such as increased biodegradability, decreased toxicity, facilitation of water and salt recovery shall be considered. In conclusion, we demonstrated the potential benefits that textile industry may gain from switching to sulfate. Our next step will be to investigate treatment of sulfate-rich textile wastewater and its effects on closing the water cycle.

\section{Acknowledgements}

This research was funded by Scientific and Technological Research Council of Turkey (TUBITAK) under the grant number 117Y194. The authors would like to thank TUBITAK support in the realization of the study.

\section{References}

Alcalá, F.J., Custodio, E., 2008. Using the $\mathrm{Cl} / \mathrm{Br}$ ratio as a tracer to identify the origin of salinity in aquifers in. Spain and Portugal. J. Hydrol 359, 189-207.

APHA, 2012. Standard methods for the examination of water and wastewater. In: Rice, E.W., Baird, R.B., Eaton, A.D., Clesceri, L.S. (Eds.), American Public Health Association (APHA), American Water Works Association (AWWA) and Water Environment Federation (WEF), twenty-second ed. (Washington, D.C., USA).

Arslan-Alaton, I., Eremektar, G., Babuna, G.F., Selcuk, H., Orhon, D., 2004. Chemical pretreatment of textile dye carriers with ozone: effects on acute toxicity and activated sludge inhibition. Fresenius Environ. Bull. 13, 1040-1044.

Arslan-Alaton, I., Eremektar, G., Germirli-Babuna, F., Insel, G., Selcuk, H., Ozerkan, B., Teksoy, S., 2005. Advanced oxidation of commercial textile biocides in aqueous solution: effects on acute toxicity and biomass inhibition. Water Sci. Technol. 52, 309-316.

Asghar, A., Raman, A.A.A., Daud, W.M.A.W., 2015. Advanced oxidation processes for insitu production of hydrogen peroxide/hydroxyl radical for textile wastewater treatment: a review. J. Clean. Prod. 87, 826-838.

Baycan, N., Thomanetz, E., Sengül, F., 2007. Influence of chloride concentration on the formation of AOX in UV oxidative system. J. Hazard Mater. 143, 171-176.

Bisschops, I., Spanjers, H., 2003. Literature review on textile wastewater characterization. volume 24. Environ. Technol. 24 (11-1), 1399-1411.

Bonakdarpour, B., Vyrides, I., Stuckey, D.C., 2011. Comparison of the performance of one stage and two stage sequential anaerobic-aerobic biological processes for the treatment of reactive-azo-dye-containing synthetic wastewaters. Int. Biodeterior. Biodegrad. 65, 591-599.

Chougule, A.S., Jadhav, S.B., Jadhav, J.P., 2014. Microbial degradation and detoxification of synthetic dye mixture by Pseudomona ssp. SUK 1. Proc. Natl. Acad. Sci. India B Biol. Sci. 84 (4), 1059-1068.

Contreras, E.M., Ruiz, F., Bertola, N.C., 2008. Kinetic modeling of inhibition of ammonia oxidation by nitrite under low dissolved oxygen conditions. J. Environ. Eng. 134, 184-190.

Davis, S.N., Whittemore, D.O., Fabryka-Martin, J., 1998. Uses of chloride/bromide ratios in studies of potable water. Gr. Water 36, 338-350.

Deeudomwongsa, P., Phattarapattamawong, S., Lin, K.Y.A., 2017. Control of disinfection byproducts (DBPs) by ozonation and peroxone process: role of chloride on removal of DBP precursors. Chemosphere 184, 1215-1222.

Eremektar, G., Selcuk, H., Meric, S., 2007. Investigation of the relation between COD fractions and the toxicity in a textile finishing industry wastewater: effect of preozonation. Desalination 211, 314-320.

Espinoza, C., Romero, J., Villegas, L., Cornejo-Ponce, L., Salazar, R., 2016. Mineralization of the textile dye acid yellow 42 by solar photoelectro-Fenton in a lab-pilot plant. J. Hazard Mater. 319, 24-33.

Fang, C., Xiao, D., Liu, W., Lou, X., Zhou, J., Wang, Z., Liu, J., 2016. Enhanced AOX accumulation and aquatic toxicity during 2,4,6-trichlorophenol degradation in a Co (II)/peroxymonosulfate/Cl-system. Chemosphere 144, 2415-2420.

Farooqi, I.H., Basheer, F., 2017. Treatment of Adsorbable Organic Halide (AOX) from pulp and paper industry wastewater using aerobic granules in pilot scale SBR. J. 
Water Process Eng. 19, 60-66.

Frijters, C.T.M.J., Vos, R.H., Scheffer, G., Mulder, R., 2006. Decolorizing and detoxifying textile wastewater, containing both soluble and insoluble dyes, in a full scale combined anaerobic/aerobic system. Water Res. 40, 1249-1257.

Garcia-Ochoa, F., Gomez, E., 2009. Bioreactor scale-up and oxygen transfer rate in microbial processes: an overview. Biotechnol. Adv. 27 (2), 153-176.

Garcia-Segura, S., Ocon, J.D., Chong, M.N., 2018. Electrochemical oxidation remediation of real wastewater effluents - A review. Process Saf. Environ. 113.

Grguric, G., Trefry, J.H., Keaffaber, J.J., 1994. Ozonation products of bromine and chlorine in seawater aquaria. Water Res. 28, 1087-1094.

Imran, M., Shaharoona, B., Crowley, D.E., Khalid, A., Hussain, S., Arshad, M., 2015. The stability of textile azo dyes in soil and their impact on microbial phospholipid fatty acid profiles. Ecotoxicol. Environ. Saf. 120, 163-168.

ISO 6341, 2012. Water quality, determination of the inhibition of the mobility of Daphnia magna straus (cladocera, Crustacea). Acute toxicity test 2012-10, 22.

Jadhav, S.B., Chougule, A.S., Shah, D.P., Pereira, C.S., Jadhav, J.P., 2015. Application of response surface methodology for the optimization of textile effluent biodecolorization and its toxicity perspectives using plant toxicity, plasmid nicking assays. Clean Technol. Environ. Policy 17, 709-720.

Jalife-Jacobo, H., Feria-Reyes, R., Serrano-Torres, O., Gutiérrez-Granados, S., PeraltaHernández, J.M., 2016. Diazo dye Congo Red degradation using a Boron-doped diamond anode: an experimental study on the effect of supporting electrolytes. J. Hazard Mater. 319, 78-83.

Khatri, A., Peerzada, M.H., Mohsin, M., White, M., 2015. A review on developments in dyeing cotton fabrics with reactive dyes for reducing effluent pollution. J. Clean. Prod. 87, 50-57.

Kovács, K., Farkas, J., Veréb, G., Arany, E., Simon, G., Schrantz, K., Dombi, A., Hernádi, K., Alapi, T., 2016. Comparison of various advanced oxidation processes for the degradation of phenylurea herbicides. Food Contam. Agric. Wastes 51, 205-214.

Lan, Y., Coetsier, C., Causserand, C., Serrano, K.G., 2017. On the role of salts for the treatment of wastewaters containing pharmaceuticals by electrochemical oxidation using a boron doped diamond anode. Electrochim. Acta 231, 309-318.

Lee, D.J., Lee, C.Y., Chang, J.S., 2012. Treatment and electricity harvesting from sulfate/ sulfide-containing wastewaters using microbial fuel cell with enriched sulfate-reducing mixed culture. J. Hazard Mater. 243, 67-72.

Liang, J., Ning, X., Sun, J., Song, J., Hong, Y., Cai, H., 2018. An integrated permanganate and ozone process for the treatment of textile dyeing wastewater: efficiency and mechanism. J. Clean. Prod. 204, 12-19.

Magdeburg, A., Stalter, D., Schlüsener, M., Ternes, T., Oehlmann, J., 2014. Evaluating the efficiency of advanced wastewater treatment: target analysis of organic contaminants and (geno-)toxicity assessment tell a different story. Water Res. 50, 35-47.

Meriç, S., Selçuk, H., Belgiorno, V., 2005a. Acute toxicity removal in textile finishing wastewater by Fenton's oxidation, ozone and coagulation-flocculation processes. Water Res. 39, 1147-1153.

Meriç, S., Selcuk, H., Gallo, M., Belgiorno, V., 2005b. Decolourisation and detoxifying of Remazol Red dye and its mixture using Fenton's reagent. Desalination 173, 239-248.

Miran, W., Jang, J., Nawaz, M., Shahzad, A., Lee, D.S., 2018. Sulfate-reducing mixed communities with the ability to generate bioelectricity and degrade textile di-azo dye in microbial fuel cells. J. Hazard Mater. 352, 70-79.

Morali, E.K., Uzal, N., Yetis, U., 2016. Ozonation pre and post-treatment of denim textile mill effluents: effect of cleaner production measures. J. Clean. Prod. 137, 1-9.

Pinheiro, H.M., Touraud, E., Thomas, O., 2004. Aromatic amines from azo dye reduction: status review with emphasis on direct UV spectrophotometric detection in textile industry wastewaters. Dyes Pigments 61, 121-139.

Popli, S., Patel, U.D., 2015. Destruction of azo dyes by anaerobic-aerobic sequential biological treatment: a review. Int. J. Environ. Sci. Technol. 12, 405-420.

Ramjaun, S.N., Yuan, R., Wang, Z., Liu, J., 2011. Degradation of reactive dyes by contact glow discharge electrolysis in the presence of $\mathrm{Cl}^{-}$ions: kinetics and AOX formation. Electrochim. Acta 58, 364-371.

Santhanam, M., Selvaraj, R., Annamalai, S., Sundaram, M., 2017. Combined electrochemical, sunlight- induced oxidation and biological process for the treatment of chloride containing textile effluent. Chemosphere 186, 1026-1032.

Sarayu, K., Swaminathan, K., Sandhya, S., 2007. Assessment of degradation of eight commercial reactive azo dyes individually and in mixture in aqueous solution by ozonation. Dyes Pigments 75, 362-368.

Selçuk, H., Eremektar, G., Meriç, S., 2006. The effect of pre-ozone oxidation on acute toxicity and inert soluble COD fractions of a textile finishing industry wastewater. J. Hazard Mater. 137, 254-260.

Selcuk, H., 2005. Decolorization and detoxification of textile wastewater by ozonation and coagulation processes. Dyes Pigments 64, 217-222.

Selcuk, H., Sene, J.J., Zanoni, M.V.B., Sarikaya, H.Z., Anderson, M., 2004. Behavior of bromide in the photoelectrocatalytic process and bromine generation using nanoporous titanium dioxide thin-film electrodes. Chemosphere 54, 969-974.

Somensi, C.A., Simionatto, E.L., Bertoli, S.L., Wisniewski, A., Radetski, C.M., 2010. Use of ozone in a pilot- scale plant for textile wastewater pre-treatment: physico-chemical efficiency, degradation by-products identification and environmental toxicity of treated wastewater. J. Hazard Mater. 175, 235-240.

Tomei, M.C., Pascual, J.S., Angelucci, D.M., 2016. Analysing performance of real textile wastewater bio-decolourization under different reaction environments. J. Clean. Prod. 129, 468-477.

Tong, T., Elimelech, M., 2016. The global rise of zero liquid discharge for wastewater management: drivers, technologies, and future. Environ. Sci. Technol. 50 (13), 6846-6855.

TS EN ISO 9562, 2004. Water Quality - Determination of Adsorbable Organically Bound Halogens AOX). Turkish Standards Institute (TS).

Turcanu, A., Bechtold, T., 2017. Cathodic decolourisation of reactive dyes in model effluents released from textile dyeing. J. Clean. Prod. 142, 1397-1405.

Ulucan-Altuntas, K., Ilhan, F., 2018. Enhancing biodegradability of textile wastewater by ozonation processes: optimization with response surface methodology. Ozone Sci. Eng. 40, 465-472.

Vacchi, F.I., Albuquerque, A.F., Vendemiatti, J.A., Morales, D.A., Ormond, A.B., Freeman, H.S., Zocolo, G.J., Zanoni, M.V.B., Umbuzeiro, G., 2013. Chlorine disinfection of dye wastewater: implications for a commercial azo dye mixture. Sci. Total Environ. 442, 302-309.

Wang, A.Q., Lin, Y.L., Xu, B., Hu, C.Y., Xia, S.J., Zhang, T.Y., Chu, W.H., Gao, N.Y., 2017 Kinetics and modeling of iodoform degradation during UV/chlorine advanced oxidation process. Chem. Eng. J. 323, 312-319.

Waring, D.R., Hallas G., ., 1990. The Chemistry and Application of Dyes Plenum Press, Newyork and London.

Xie, Y., Chen, L., Liu, R., 2017. AOX contamination status and genotoxicity of AOXbearing pharmaceutical wastewater. J. Environ. Sci. (China) 52, 170-177.

Xie, Y.W., Chen, L.J., Liu, R., Tian, J.P., 2018. AOX contamination in Hangzhou Bay, China: levels, distribution and point sources. Environ. Pollut. 235, 462-469.

Yang, Y., Pignatello, J.J., 2017. Participation of the halogens in photochemical reactions in natural and treated waters. Molecules 22, 1684.

Yoon, S.H., 2015. Advances in Water and Wastewater Transport and Treatment, Membrane Bioreactor Processes: Principles and Applications. CRC Press, Florida, USA, pp. 258.

Yuan, R., Ramjaun, S.N., Wang, Z., Liu, J., 2012. Photocatalytic degradation and chlorination of azo dye in saline wastewater: kinetics and AOX formation. Chem. Eng. J. 192, 171-178.

Zanoni, M.V.B., Sene, J.J., S.H., A.,M.A., 2004. Photoelectrocatalytic production of active chlorine on nanocrystalline titanium dioxide thin-film. Electrodes 38, 3203-3208.

Zeng, Q., Hao, T., Mackey, H.R., Wei, L., Guo, G., Chen, G., 2017. Alkaline textile wastewater biotreatment: a sulfate-reducing granular sludge based lab-scale study. J. Hazard Mater. 332, 104-111.

Zhang, H., Qu, J., Liu, H., Zhao, X., 2009. Characterization of isolated fractions of dissolved organic matter from sewage treatment plant and the related disinfection byproducts formation potential. J. Hazard Mater. 164, 1433-1438. 